\title{
FRANÇOIS DE TOTT (1733 - 1793) \\ ŽIVOT A DIELO JEDNÉHO OSVIETENÉHO DIPLOMATA
}

\author{
ZSOLT HO R B U L Á K - FERENC T Ó T H
}

\begin{abstract}
HORBULÁK, Zsolt - TÓTH, Ferenc. François de Tott (1733-1793). The life and work of an Enlightenment Diplomat. Historický časopis, 2019, 67, 2, pp. 215-239, Bratislava.

This study deals with François Baron de Tott (1733-1793), a French diplomat, general and writer. The paper is divided into three parts. In the first, we present the life of the baron, summarizing his positions, diplomatic missions and service to France, as well as his destiny as a representative of the second generation of exiles in France from the Rakoczi revolt who returned to the land of his ancestors. The following part is devoted to the origin of the baron's family. This research was done in Slovak archives to prove his Hungarian and Slovak roots. Finally, we analyse de Tott's Memoirs, which made the personality of the baron immortal, from the literary, historical, political and personal points of view.

Key words: François de Tott. Diplomacy. Ottoman Empire. Military reforms. Memoirs.
\end{abstract}

DOI: https://doi.org/10.31577/histcaso.2019.67.2.2

Osoba baróna Françoisa de Totta je známa nielen slovenskej vedeckej, ale aj laickej verejnosti. O jeho životnej dráhe a literárnom diele vznikli viaceré vedecké state, ${ }^{1}$ náučné práce, ${ }^{2}$ dokonca na túto tému bola obhájená aj dizertačná prá-

1 HORBULÁK, Zsolt. Novšie fakty o genealógii rodu baróna Františka Tótha. In Acta Historica Posoniensia, 2010, č. 13, s. 126-144. ISSN 1338-7588; HORBULÁK, Zsolt. Osmanská ríša očami uhorského vzdelanca 18. storočia. Memoáre Františka Tótha a ich historicko-literárna hodnota. In Nové historické rozhl'ady, 2011, roč. 1, č. 2, s. 37-46. ISSN 1338-4813; HORBULÁK Zsolt. Tóth Ferenc báró élete és munkássága. In Fórum, 2007, roč. 10, č. 1, s. 129142. ISSN 1335-4361; HORBULÁK Zsolt. A Kelet egy diplomata szemével. François de Tott Emlékiratai. In Irodalmi Szemle, 2007, roč. 50, č. 1, s. 54-61, ISSN 1336-5088.

2 DANIŠ, Miroslav. V službách francúzskeho král'a. In Historická revue, 2001, roč. 12, č. 10, s. 16-17; HORBULÁK, Zsolt. František Tóth - zabudnutý diplomat zo Slovenska. In Zahraničná politika, 2006, roč. 10, č. 1, s. 13-14; HORBULÁK, Zsolt. Andrej a František Tóthovci. In História, 2006, roč. 6, č. 5, s. 34-36; HORBULÁK, Zsolt. François de Tott - Tóth Ferenc. Egy franciaországi kuruc emigráns kimagasló életútja. In Múltunk Emlékei, 2006, roč. 10, č. 10 , s. 9-10. 
ca. ${ }^{3}$ Je nepopieratel'ným faktom, že jeho osoba je ovel’a známejšia v Mad’arsku. ${ }^{4}$ Najviac publikácií o barónovi však vzniklo vo francúzskom jazyku, ${ }^{5}$ ked’že de Tott celý svoj aktívny život prežil v službe francúzskeho král'a. Popri barónovi zohral historickú úlohu i jeho otec Andrej Tóth, ${ }^{6}$ a tiež mladší brat Andrej. ${ }^{7}$

François baron de Tott sa stal známym na základe svojich Spomienok. Pôvodný názov diela je Mémoires du baron de Tott sur les Turcs et les Tartares (Spomienky baróna Totta na Turkov a Tatárov). Prvé vydanie Memoárov uzrelo svetlo sveta roku 1784 v Amsterdame a čoskoro sa objavili aj preklady. Na kom-

3 HORBULÁK, Zsolt. František Tóth a jeho rodina v kontexte európskej diplomacie 18. storočia. Bratislava: Univerzita Komenského, Filozofická fakulta, 2006, 148 s.

4 PALÓCZI Edgár: Báró Tóth Ferenc a Dardanellák megerösitôje. Budapest: Kiadja a Vörös Félhold támogatására alakult országos bizottság, 1916; TÓTH Ferenc: Egy tarcsafürdői emlék, Báró Tóth Ferenc (1733-1793) élete és munkássága. In Vasi Szemle, 2001, roč. 55, č. 1, s. 31-42. HU-ISSN 0505-0332; ZACHAR, József: Der Weg des französischen Generals ungarischer Abstammung François Baron de Tott (1733-1793) von Paris nach Bad Tatzmannsdorf. In 17. Österreichischer Historikertag, Eisenstadt, 1987. s. 193-195; HORBULÁK Zsolt. Adalékok Tóth Ferenc báró származásához. In Vasi Szemle, 2005, roč. 59, č. 6, s. 734-744. HU-ISSN 0505-0332; TÓTH Ferenc. Egy magyar származású francia diplomata életpályája. François de Tott báró (1733-1793). Budapest: MTA Bölcsészettudományi Kutatóközpont Történettudományi Intézet, 2015, 314 s. ISBN 9789639627956.

5 BOPPE, Auguste. La France et le „militaire turc“ au XVIIIe siècle. In Feuilles d'histoire $d u X_{V I I}{ }^{e}$ au XXe siècle, 1912, s. 387-402, 490-501; LAULAN, Robert. Un artilleur français improvisé à Constantinople au dix-huitième siècle, le baron de Tott. In Revue d'Artillerie, 1932, tome CX, s. 343-363, 392-411, 460-481; 1933, tome CXI, s. 41-53; SAMAN, Édouard. François de Tott, diplomate et baron de Louis XVI. In Marseille, 1979, č. 118, s. 8495; DEHÉRAIN, Henri. La mission du baron de Tott et de Pierre Ruffin auprès du khan de Crimée de 1767 à 1769. In Revue de l'histoire des colonies françaises, 1923, č. 11, s. 1-32; FARNAUD, Christophe. Culture et politique: la mission secrète du baron de Tott au Levant (1776-1779). Mémoire de maîtrise préparé sous la direction de Jean Meyer. Paris IV: Université de Paris-Sorbonne, 1988; FONT-RÉAULX, Anne de. Présence française dans l'Empire ottoman au XVIIIe siècle: le baron de Tott (1733-1793). In Thèse soutenue en 1969 à l'Ecole des Chartes; TÓTH, Ferenc. Un souvenir français de Bad Tatzmannsdorf. In TÓTH, Ferenc. Le Département de Vas et la France dans l'histoire - Études françaises de Szombathely I. Szombathely 2000. s. 55-64. ISBN 963929019X; TÓTH, Ferenc. Voltaire et un diplomate d'origine hongroise en Orient. In Cahiers d'études hongroises, 1995, č 7, s. 78-86. ISSN 1149-6525; TÓTH, Ferenc. Un diplomate militaire français en europe orientale À la fin de l'ancien régime. La carrière de françois baron de Tott (1733-1793). Istanbul: Isis, 2011, 289 s. ISBN 9789754284300.

6 SEGEŠ, Vladimír. Najmladší kuruc. In Obrana, 2004, roč. 14, č. 9, s. 21; HORBULÁK, Zsolt. V službách francúzskeho král'a. Príbeh husárskeho generála Andreja Tótha. In Historická revue, 2005, roč. 14., č. 5-6, s. 28-29; HORBULÁK Zsolt. Rákóczi apródja. Tóth András francia brigadéros élete. In Múltunk Emlékei, 2006, roč. 10, č. 6, s. 6-7.

7 TÓTH Ferenc. Casanova magyar barátja. In Ambra, 2000, č. 1, s. 237-240; TÓTH, Ferenc. André de Tott, un ami de Casanova, capitaine de hussards. In Vivat Hussar, 2003, č. 38, s. 86-89. ISSN 1158-3401; HORBULÁK, Zsolt. André de Tott - Dobrodruh zo Slovenska. In Historická revue, 2006, roč. 17, č. 9-10, s. 52-53. 
pletný mad'arský preklad sa však muselo čakat' až do roku $2008^{8}$ a slovenský ešte stále nevznikol.

Podl'a nášho názoru postavou Františka Tótha by sa mala zaoberat' aj slovenská historiografia. Dôvody sú tieto:

- François de Tott bol takou výnimočnou osobnost'ou, že je vhodné oboznámit' slovenských čitatel'ov s jeho životom;

- jeho rodokmeň sa v súčasnosti dá zrekonštruovat' len obtiažne, ale jeho slovenský pôvod je napriek tomu nespochybnitel'ný;

- niektoré časové úseky jeho života sa dajú skúmat’ len v slovenských archívoch a knižniciach;

- po návrate do Uhorska sám barón, ked' potreboval potvrdenie o svojom zemianskom pôvode, oslovil stolicu, ktorá je dnes súčast'ou Slovenska.

V prvej časti štúdie zhrnieme životnú dráhu Françoisa de Totta, potom si všimneme jeho vzt'ah k Slovensku a nakoniec sa budeme zaoberat' jeho $\mathrm{Me}$ moármi.

$* * *$

Francúzsku vetvu uhorskej zemianskej rodiny založil otec Françoisa Andrej Tóth (André de Totte), ktorý po skončení rákociho povstania emigroval do zahraničia. Nenasledoval však Františka II. Rákociho do Pol'ska a neskôr do Francúzska, ale sa usadil na území Osmanskej ríše. V priebehu niekol'kých rokov si osvojil turecký a tatársky jazyk a podarilo sa mu nadviazat' dobré vzt'ahy s mnohými členmi osmanskej elity. Roku 1720 sa vypravil do Francúzska, kde vstúpil do novozriadeného berčéniovského husárskeho pluku. Vzhl'adom na jazykové schopnosti a kontakty ho často vysielali na diplomatické misie na územie Turkov a Tatárov.

Hoci francúzska diplomacia už aj predtým zamestnávala uhorských agentov, ${ }^{9}$ v 18. storočí sa stal najznámejším z nich práve Andrej Tóth. Vd’aka svojmu talentu rýchlo postupoval na diplomatickom rebríčku. Na znak dôvery, za vlády

8 François de Tott báró emlékiratai a törökökröl és a tatárokról. Prekl. Dr. Ferenc Tóth, Éva Neofitu, Dr. Zoltán Jeney. Szombathely: Vasi Szemle, 2008, 295 s. ISBN 97896387612.

9 Na základe záznamov prvým známym francúzskym diplomatom v Konštantínopole bol uhorský zeman Ján Frankopán, syn Andreja Frankopána. K tomu: SAINT-PRIEST, comte de. Mémoires sur l'ambassade de France en Turquie. Paris: Ernest Leroux, 1877, s. 179; SPULER, Bertold. Die europäische Diplomatie in Konstantinopel bis zum Frieden von Belgrad (1739) 3. Teil: Liste der in Konstantinopel anwesenden Gesandten bis in die Mitte des 18. Jahrhunderts; ÜBERSBERGER, Hans - HANISCH, Erdman (eds.). Jahrbücher für Kultur und Geschichte der Slaven Band XI. Breslau 1935, s. 345; BACQUÉ-GRAMMONT, Jean-Louis KUNERALP, Sinan - HITZEL, Frédéric. Représentants permanents de la France en Turquie (1536-1991) et de la Turquie en France (1797-1991). Istanbul: Editions Isis, 1991, s. 1. ISBN 9782906053229 
L’udovíta XV., ho zasvätili do tajnej král'ovskej diplomacie známej ako secret du roi. ${ }^{10}$

Prvorodený syn Andreja Tótha, ktorý sa po celý svoj život podpisoval ako François de Tott, sa narodil 17. augusta 1733 vo francúzskej dedinke Chamigny pri La Ferté-sous-Jouarre. Jeho matka Marie Ernestine de Pesselier pochádzala z miestnej šl'achtickej rodiny. Mladý François v roku 1742 ako devätročný vstúpil do berčéniovskeho husárskeho pluku ako kornét. Zúčastnil sa viacerých výprav vo vojne o rakúske dedičstvo a v bitke pri Lawfelde bol aj ranený. ${ }^{11}$ Mladý husársky dôstojník vd’aka svojim schopnostiam, s povolením francúzkej vlády, mohol sprevádzat' svojho otca na ceste do Konšatntínopolu, aby sa aj on mohol naučit' hovorit' po turecky a spoznat' miestne zvyky. V hlavnom meste Osmanskej ríše, vo štvrti Péra, od roku 1669 existovala škola na vzdelávanie tlmočníkov (école des jeunes de langue), ktorá vychovala mnoho známych tlmočníckych dynastií, a taktiež si tam zdokonal'ovali svoje jazykové vedomosti viacerí vedci a orentalisti. ${ }^{12}$ Mladý de Tott sa snažil pokračovat' v otcových šl'apajach. Tieto „učňovské roky“ zásadne ovplyvnili kariéru mladého diplomata. Rovnako osudovým sa stal jeho vzt'ah a priatel'stvo s grófom Vergennesom, francúzskym vel'vyslancom, neskorším ministrom zahraničných vecí Francúzska. François sa už počas svojho prvého konštantínopolského pobytu oženil. Jeho manželkou sa stala Marie de Rambaud, šl'achtičná z Lyonu, ktorá mu porodila dve dcéry. ${ }^{13}$

Na mladíka zapôsobilo ovzdušie panujúce na francúzskom vel'vyslanectve v Konštntínopole, kde vel'koryso podporovali umenie. Najviac ho ovplyvnil maliar Antoine de Favraynak, ktorý v tom čase pracoval na zákazkách pre grófa Vergennes. V tomto prostredí sa François začal venovat' umeniu a písaniu kratších literálnych diel.

Roku 1763 François de Tott pricestoval do Francúzska. Dlho posielal žiadosti kniežatovi Choiseul, ministrovi zahraničných vecí, aby mu pridelili diplomatickú úlohu v Turecku. Namiesto osmanskeho impéria ho vyslali do susedného neuchâtelskeho kniežatsva, aby informoval francúzsky dvor o sporoch medzi pruskou vládou a miestnymi obyvatel'mi. Roky 1766 až 1768 boli v tomto kniežastve búrlivé. ${ }^{14}$ Napriek stabilnému politickému a hospodárskemu životu sa

10 VANDAL, Albert. Une ambassade française en Orient sous Louis XV: La mission du marquis de Villeneuve 1728-1741. Paris: Plon 1887, s. 197.

11 TÓTH, Ferenc. Un Hongrois qui a sauvé 1‘Empire ottoman. In Mediterrán Tanulmányok Études sur la région méditerranéenne, 1997, č. 7, s. 66. ISSN 0238-8308.

12 HITZEL, Frédéric. Les Jeunes de langue de Péra-lès-Constantinople. In Dix-Huitième Siècle, 1996, č. 28, s. 57-70. ISSN 0070-6760.

13 MÉZIN, Anne. Les consuls de France au siècle des Lumières (1715-1792). Paris: Imprimerie Nationale, 1995. s. 568. ISBN 2110891580.

14 Pozri k tomu BOREL, Arnold. Le conflit entre les Neuchâtelois et Frédéric le Grand sur la question de la forme des impôts du pays de Neuchâtel (1766-1768). Neuchâtel: Attinger, 
medzi pruským král’om sídliacim v d’alekom Brandenbursku a miestnym obyvatel'stvom vynorili spory fiškálneho rázu, ktoré sa časom stupňovali. Aj ked' pravú úlohu François de Totta miestne úrady odhalili a z kniežatsva ho vyhostili, podl’a listu kniežat’a Choiseula svoju misiu plnil s vel'kým nadšením. ${ }^{15}$

Napriek neúspechu neuchâtelskej cesty sa barónovi podarilo preukázat' svoju šikovnost', a preto mu čoskoro pridelili d’alšiu diplomatickú úlohu, ktorá bola primeranejšia - vymenovali ho za konzula na dvore krymského chána. Post francúzskeho konzula v Bahčiseráji nebol až tak dôležitý. ${ }^{16}$ Často ho zastávali lekári či dobrodruhovia. V priebehu 18. storočia tu pôsobili diplomati uhorského pôvodu, okrem iných aj Andrej Tóth. Váha konzulátu rástla paralelne s rastom ruskej moci v tejto oblasti, čo stále viac znepokojovalo Francúzsko, tradičného spojenca Osmanskej ríše. Knieža Choiseul sa snažil, aby vypukla d’alšia rusko-turecká vojna. Očakával, že tým napomôže dosiahnut' politickú nezávislost' Pol'ska a zvýši vplyv Francúzska. Dosiahnutie tohto medzníka bolo úlohou krymskej misie Françoisa de Totta.

Politický konflikt na rusko-tureckej hranici v júli roku 1768 vyústil do vojny. De Tott v sprievode orientalistu Pierra Ruffina strávil dva roky v blízkosti viacerých tatárskych chánov a pravidelne informoval francúzske ministerstvo zahraničných vecí o vojenskom a diplomatickom dianí. ${ }^{17}$ Pobyt baróna ukončila smrt' chána Krym-Gireja v roku 1769. Jeho následník už neprejavil záujem o služby francúzskeho konzula, a tak de Tott odcestoval do Konštantínopolu. Do osmanského hlavného mesta, kde panoval chaos a strach z vojny, dorazil 11. apríla $1769 .{ }^{18}$ Vd'aka svojej odbornej a jazykovej pripravenosti si čoskoro získal priazeň sultánových ministrov. V prvom rade navrhoval, aby sa pokračo-

1898; PETITPIERRE, Olivier. Histoire abrégée des troubles de Neuchâtel pendant les années 1766, 1767 et 1768. Neuchâtel: Petitpierre et Prince, 1832; PURY, Georges de. Un assassinat politique à Neuchâtel en 1768. L'avocat général Gaudot. In Musée Neuchâtelois, 1875 , s. $199-204,236-249,292-296 ; 1876$, s. 13-19; 1913 s. 21 a passim, s. 97 a passim, s. 178 a passim, s. 193 a passim, s. 261 a passim.

15 LIVET, Georges (ed.). Recueil des instructions données aux ambassadeurs et ministres de France des traités de Westphalie jusqu 'à la Révolution française. Tome XXX, Suisse Tome second (Genève, Les Grisons, Neuchâtel et Valangin, 1'Evêché de Bâle, Le Valais), Paris, 1983, s. 805-816. ISBN 2222029422; TÓTH, Ferenc. La mission du baron de Tott à Neuchâtel en 1767. In Revue Historique Neuchâteloise, 2003 avril-juin č. 2, s. 133-159. ISSN 14225182.

16 Pozri k tomu: MÉZIN, ref. 13.

17 DEHÉRAIN, Henri. La mission du baron de Tott et de Pierre Ruffin auprès du khan de Crimée de 1767 à 1769. In Revue de l'histoire des colonies françaises, 1923, č. 11, s. 1-32; TÓTH, Ferenc. La mission du baron de Tott en Crimée. In Archivum Ottomanicum, 2002, č. 20, Ed. György Hazai, s. 131-165. ISSN 0378-2808.

18 Centre des Archives Diplomatiques de Nantes, série Saint-Priest (d’alej CADN, Saint-Priest) 44, s. 767. 
valo v zdokonal'ovaní delostrelectva, čo paša Bonneval odporúčal sultánovi už na začiatku 18. storočia. Teraz túto úlohu zverili jemu.

Ked' osmanská flotila 5. júla 1770 pri Česme utrpela zdrvujúcu porážku, situácia sa vyhrotila a vynútila si posilnenie pevností nachádzajúcich sa na pobreží dardanelských úžin. Na odporúčanie nového francúzskeho vel'vyslanca grófa Saint-Priest Vysoká porta poverila touto úlohu Françoisa de Totta. ${ }^{19}$ Barón zistil, že nielen pevnosti, ale aj ich obrancovia sa nachádzajú v zanedbanom stave. Nakoniec sa ruské lode iba raz pokúsili prerazit' Dardanely. Barón pomocou rozžeravených delových gúl' tento pokus úspešne odrazil. ${ }^{20}$

Hned' po tom dostal d'alšiu úlohu - zreformovat' turecké delostrelectvo podl'a európskeho vzoru. ${ }^{21}$ Tott nebol delostrelcom z povolania, avšak z praxe poznal princípy fungovania zbraní tohto druhu. Francúzske delostrelectvo v tom čase patrilo medzi najvyspelejšie v Európe, o čo sa postarali inžinieri Saint-Rémy, Bélidor či Gribeauval. Knieža Choiseul, najvýznamnejší podporovatel' vojenských reforiem počas sedemročnej vojny, úlohu zveril do rúk Gribeauvala, ktorého rýchlopalné delá (système Gribeauval) zabezpečili prevahu francúzskemu delostrelectvu až do revolučných rokov a napoleonských vojen. Tott svoje úspechy čoskoro verejne demonštroval a obyvatel'stvo Konštantínopola už v decembri 1770 na vlastné oči mohlo vidiet' nové delá. ${ }^{22}$

Na začiatku roka 1771 bola mladému husárskemu dôstojníkovi zverená d’alšia úloha - vybudovat' zlievareň na delá, založit’ školu na výchovu delostrelcov a zriadit' nové delostrelectvo na základe európskeho vzoru. ${ }^{23}$ Delostrelcov, ktorí sa dostali priamo pod velenie baróna, nazývali süratčikmi. Jeho inovácie neznamenali len reštrukturalizáciu delostrelectva, ale v dlhšom horizonte aj udomácnenie európskeho ducha $\mathrm{v}$ tureckej armáde. $\mathrm{K}$ modernizačným zmenám patrilo aj zavedenie moderných uniforiem západného vzoru, bajonetu či drsnej disciplíny. ${ }^{24} \mathrm{Na}$ žiadost' sultána zostrojil i pontónové mosty. ${ }^{25}$

Mustafa III. sa prejavil ako zanietený podporovatel' reforiem, ale mnohí iní osmanskí vel'moži prijímali úsilie baróna s nedôverou. ${ }^{26}$ Vzhl’adom na úspechy „neveriaceho d’aura“" sa príslušníci tradičného tureckého delostrelectva snažili zachovat' si svoju autoritu a zmarit' reformné pokusy.

19 CADN, Saint-Priest, ref. 18, 45, s. 407.

20 Mémoires III, s. 34-37.

21 CADN, Saint-Priest, ref. 18, 45 s. 497.

22 CADN, Saint-Priest, ref. 18, 45 s. 587-588.

23 CADN, Saint-Priest, ref. 18,48 s. 265.

24 Mémoires III, s. 116-117. Oddiel süratčikov znovu zriadili počas vel'kovezíra Halîl Hamîd (1782-1785) pašu. HITZEL, ref. 12, s. 296.

25 CADN, Saint-Priest, ref. 18, 46 s. 147-148, 213-214, 219.

26 CADN, Saint-Priest, ref. 18, 46 s. 220. 
O činnosti Françoisa de Totta v Osmanskej ríši súdobé médiá pravididelne informovali a s otvorenou iróniou opisovali úsile francúzskeho dôstojníka. ${ }^{27}$ Meno baróna sa na stránkach Gazette de France objavilo 14. júla 1776, po jeho návrate do Francúzska. ${ }^{28} \mathrm{Na}$ správu reagovala aj cárovná Katarína vo svojich listoch adresovaných Voltairovi. ${ }^{29} \mathrm{Na}$ strane druhej takáto propaganda urobila reklamu Tottovým Spomienkam vydaným v roku $1784 .^{30}$

Roku 1777, na návrh ministerstva námorníctva, baróna vymenovali za inšpektora francúzskych obchodných kolónií na pobreží Stredozemného mora. V rovnakom čase ho poverili aj d’alšou tajnou misou - vypracovat' plán na obsadenie Egypta. Po svojom návrate predložil francúzskemu dvoru dôkladne vypracovanú vojenskú koncepciu. ${ }^{31}$ Jeho úsilie v prospech egyptskej expedície zaujalo aj král'a, avšak gróf Vergennes bol v tom čase zaneprázdnený vojnou v Severnej Amerike. Tottove memorandum tak na dlhý čas - až do Napoleonovej egyptskej výpravy v roku 1798 - zostalo na papieri.

Po zmarení svojich plánov sa François de Tott stiahol z verejného života a venoval sa písaniu Spomienok. Roku 1785 dostal svoju poslednú úlohu. Vymenovali ho za guvernéra pevnosti v severofrancúzskom mestečku Douai. ${ }^{32}$ Post musel opustit' kvôli vzbure vojakov v roku 1790. Tak ako mnohí d'alší predstavitelia ancién regimu, aj barón volil cestu zahraničnej emigrácie. Precestoval viacero štátov a nakoniec sa rozhodol vrátit’ do vlasti predkov. Svoj pôvod nikdy nezapieral a aj vo Francúzsku hrdo nosil rodinný erb. Preto neprekvapuje, že sa obrátil na uhorského král'a Františka I. so žiadost'ou o zrušenie politického trestu udeleného jeho otcovi a dostal amnestiu.

Posledné roky života strávil v dedinke Tarcsafürdő vo Vašskej stolici, ${ }^{33}$ na panstve grófa Teodora Batthyányiho. Svoju povahu nezaprel ani na sklonku života. Dedinčania neraz vídali čudné svetlá sprevádzúce jeho pokusy, ako prenikajú cez okná barónovo domu, a preto čoskoro premenovali obydlie na „bosorkin dom“ (Hexenhaus). Po Tottovej smrti, v októbri roku 1793, daroval jeho hostitel' prístrojové vybavenie král’ovskému katolíckemu gymnáziu v Szombathelyi, a tak mohol byt' v škole založený prvý prírodovedecký kabinet. Obyvatelia

27 Pozri k tomu: Les Gazettes Européennes de langue française (XVIIe-XVIIIe siècles). Table ronde internationale Saint-Étienne, 21-23 mai 1992. Saint-Étienne, 1992.

28 Gazette de France, 17. júla 1776.

29 TÓTH, ref. 5.

30 LAURENS, Henry. Les origines intellectuelles de l'expédition d'Egypte. L'orientalisme islamisant en France (1698-1798). Paris; Istanbul: Isis, 1984. ISBN 2906053023.

31 Pozri k tomu: CHARLES-ROUX, François. Le projet français de conquête de l'Égypte sous le règne de Louis XVI. Le Caire, 1929.

32 Archives Municipales de Douai (Archív mesta Douai, Francúzsko), série BB 28, s. 55.

33 Dnes Bad Tatzmannsdorf, Rakúsko. 
dediny v roku 1972 na počest' baróna postavili symbolický hrob na cíntoríne v Tatzmannsdorfe.

\section{$* * *$}

Život Françoisa barona de Totta, napriek úspechu jeho Spomienok, dodnes zostal zabudnutou a navyše záhadnou kapitolou novodobých dejín diplomacie. Na jednej strane bola jeho činnost' od mladosti spätá s tajnou diplomaciou, na strane druhej si ho ako kozmopolitného človeka vtedajšej doby dlho nevšímali národné historiografie dneška. $Z$ uvedených dôvodov jeho životopis dlho nebol komplexne spracovaný. L'udia mali o ňom často anachronistickú predstavu. Raz ho vnímali ako šarlatána bez akýchkol'vek zábran, inokedy ho považovali za osvieteného filozofa. Neraz ho kritizovali aj za jeho postoje ku kolonizácii, nehovoriac o jeho nevd’ačnom úsilí o udržanie chátrajúceho osmanskeho impéria.

Pôvod baróna bol taktiež dlho zahmlený. Podl'a niektorých bol Švéd, ${ }^{34}$ naopak, Voltaire ho považoval za francúzskeho renegáta. ${ }^{35}$ Turci - napriek neskrývanému obdivu - ho vnímali ako francúzskeho šarlatána. Spomína sa aj jeho uhorský pôvod, ba dokonca ho pokladali za uhorského zemana vo francúzskych službách, pričom zabúdali na to, že on sa už narodil vo Francúzsku. Problémy prehlbuje aj fakt, že jeho brat taktiež vstúpil do služieb francúzskej diplomacie a ich činnost' bola podobná. Na základe najnovších výskumov o pôvode baróna de Totta môžeme povedat' toto.

Mad'arská historiografia už v prvej polovici 19. storočia akceptovala, že barónova rodina má uhorský pôvod. ${ }^{36} \mathrm{~V}$ prácach, ktoré vznikli $\mathrm{v}$ druhej polovici stroročia sa už spomína aj prívlastok , nitriansky““. ${ }^{37}$ Prvé vedecké bádanie o pôvode rodiny baróna Totta uskutočnil Edgár Palóczi, ktorý na základe archívnych materiálov konštatoval, že Andrej Tóth sa jednoznačne narodil 26. marca 1698 v Nitre. Tento údaj preberajú aj moderní mad'arskí historici. ${ }^{38}$

Genealogické výskumy k tejto tematike sú už dnes vel'mi obtiažne, lebo dokumenty sa zachovali len čiastočne. Faktom však je, že v Oblastnom archíve

34 ROCHEFOUCAULD, François de la. Souvenirs du 10 août 1792 et de l'armée de Bourbon. Paris: Calmann Levy, 1929.

35 Pozri k tomu TÓTH, Ferenc. Voltaire et un diplomate d'origine hongroise en Orient. In Cahiers d'études hongroises, 1995, č. 7, s. 83. ISSN 1149-6525.

36 SÁNDOR, István. Tótról. In Sokféle. Győr 1791, s. 53-55; Lakos János. Emlékezet báro Tott Ferenczre. In Tudománytár, 1836/II., X., Buda, s. 129-159; KÖRÖSY László. Báró Tót. In Hasznos mulatságok, 1836 február 17, č. 17, s. 129.

37 THALY, Kálmán. A Szuezi-csatorna magyar tervezője a mult században. In Egyetértés, 5. apríla 1888; JANKÓ ml., János. Báró Tóth Ferenc utazása Egyiptomban 1771-ben. In Földrajzi Közlemények, 1889, zv. 17, Budapest, s. 329-344; TOCSEK, Helén. A bujdosó fia. Nyitrai báró Tóth Ferenc eredeti iratai nyomán az éretebb ifjúság számára. Budapest: Méhner Vilmos kiadása, 1892.

38 ZACHAR, József. Idegen hadakban. Budapest: Magvető, 1984. s. 221. ISBN 9631401316. 
v Ivanke pri Nitre sa nachádzajú dokumenty, ktoré hovoria o rodokmeni Françoisa de Totta. Medzi spismi je aj podanie zo 7. mája 1793, ktorým barón oslovil Nitriansku stolicu a požadoval potvrdenie svojho zemianskeho pôvodu. ${ }^{39}$ Stolica žiadost' zaevidovala 9. mája uvedeného roku.

Na túto požiadavku vicenotár Nitrianskej stolice Pavol Rudňanský už 10. mája odpovedal kladne. Na základe vyjadrenia kongregácie okrem iného poslal aj výpis z matriky: „Roku 1698, dňa 26. marca narodený a pokrstený bol chlapec menom Ondrej, rodičov Mikuláša Tótha a Anny, jeho manželky, a krstných rodičov Michala Fabiana a Alžbety Tóthovej v Nitre. Na hodnovernost’ čoho som sa podpisal. V Nitre 10. mája 1793. Jozef Bleho, nitriansky farár." "40 Ďalej potvrdzuje, že podl'a súpisu šl'achty v Hornom meste Nitre žili predkovia rodiny Andreja a Františka Tótha. Toto potvrdil aj snem Nitrianskej stolice. ${ }^{41}$

39 „Inclyta universitas! Domini Domini gratiosissimi colendissimi! Infrascriptus de nobili Hungara Stirpe Tothiana Originem trahens peroptaret semet ad eandem deducere, ut et in exteris Conditionem Nobilitatis suae testimoniis perhibere posset, ex eoque supplex est apud Inclytam Universitatem in eo, quatenus Nobiles Tothianos (ad quos semet deducere Nobilitatemque suam legitimare intendit) in gremio Inclyti Comitatus Nittriensis existere, ac prearogativis Nobilitaribus perffrui pro intermali sui directione attestari dignaretur, perseverando Inclytae Universitatis. Nittriae 7 a Maii 1793, Servus humilimus, Andreas Toth, Filius Nicolai ex Civitate Nitria oriundus. Dorzálna poznámka: Ad Inclytam Universitatem Comitatus Nittriensis humilima Instantia Andreae Tóth Nittria oriundi, qui sub Anno 1706um ex Regno emigraverat, ac Testimonialibus super Nobilitate provideri cuperet pro Testimonio interimaliter super eo clarigendo, quod Familia Nobilis Tothiana in Inclyto Comitatu Nittriensi praexistat supplicantis. Present. 9 a Maii 1793. Extradetur sub signato Notarii. " List v preklade znie takto: ,,Slávne spoločenstvo! Páni najslávnejší. Dolupodpisaný, pochádzajúci z uhorskej šlachty Tótovcov, predkladám žiadost', aby mi ráčili poskytnút'svedectvo o mojom šlachtickom stave, $k$ čomu žiadost' ku slávnemu spoločenstvu predkladám $k$ tomu, že šlachtici Tótovci (ku ktorým svoje šlachtictvo vztahujem) ku spoločenstvu šlachticov slávnej stolice Nitrianskej patria a výsady šlachtické uživajú, čo slávne spoločenstvo potvrdit' ráčilo. V Nitre 7. mája 1793, Ponižený služobník Ondrej Tóth, syn Mikuláša, pochádzajúci z mesta Nitry. “ Dorzálna poznámka: „,Ku slávnemu spoločenstvu župy Nitrianskej ponižená žiadost' Ondreja Tótha pochádzajúceho z Nitry, ktorý pred rokom 1706 odišiel z královstva a svedectvo o svojej nobilite vydat' požiadal pre svedectvo na jej ozrejmenie, že šlachtická rodina Tóthovcov $v$ slávnej župe Nitrianskej pôsobí, požaduje. Dané 9. mája 1793. Vydané pod podpisom notára. " Štátny oblastný archív v Nitre (d’alej ŠOA), Nobilitár Tóth XII. 804.

40 ŠOA, ref. 39.

41 Výpis zo zápisnice Nitrianskej stolice: „Pro Illustrissimo Domino Generali Barone Andrea Tóth sequens Testimonium extradatum est: Infrascriptus I(nclyti) Comitatus Nittriensis Juratus Primarius Vice Notarius tenore presentium recognosco. Quod posteaquam Illustrissimus Baro Andreas Tóth filius Nicolai condam Tóth generalis Campi vigiliarum Praefectus tenore memorialis sui Universitati praelibati I(nclyti) Comitaus exhibiti id an Familia Tóth Nobilis in Comitatu hocce praeexistat, perquiri et recognosci petiisset erga suplicem ejusmodi recursum I(nclyti) Comitatus istius Nittriensis Regestria Nobilium excussa sunt in iisdemque compertum est. Quod non tantum in compluribus Curialibus comitatus hujus locis sed etiam in Superiori Civitate Nittria I(nclyto) Comitatui nominis ejusdem adjacente, unde praetitulatus Dominus Baro testante Matricula Civitatis Nittriensis ortum duceret. Nobilis Familiae Tóth 
V súvislosti s touto žiadost'ou sa vynára niekol'ko otázok. Žiadatel’om bol Andrej Tóth, syn Mikuláša, ktorý pochádzal z mesta Nitry a ktorý v roku 1706 musel opustit' Uhorsko. Tento muž úctivo žiada Nitriansku stolicu, aby mu testimoniom potvrdili jeho zemiansky pôvod vzhl'adom na to, že pôvod jeho rodiny je práve tam. Fakty uvedené v žiadosti však nezodpovedajú pravde. Podpísaný Andrej Tóth v roku 1793 už nežil a neemigroval z Uhorska v roku 1706, ale až v roku 1711, po szatmárskom mieri. Palóczi však pri svojom logickom postupe nepochybuje o tom, že žiadost' bola napísaná na podnet Françoisa de Totta. Barón de Tott po svojom návrate potreboval potvrdenie o svojom pôvode, po vypuknutí revolúcie totiž musel rýchlo opustit' Francúzsko a zanechat' tam všetky písomnosti, vrátane dokladu o svojom francúzskom baronáte. Barón v tom čase už býval niekol'ko mesiacov v Uhorsku, v dedine Bad Tatzmannsdorf. To, prečo sa François podpísal ako Andrej, dnes nevieme vysvetlit'. Na jednej strane je to mätúci faktor, na strane druhej je potvrdením toho, že je synom Andreja Tótha. Palóczi dokonca považuje za pravdepodobné, že túto inštanciu nepísal barón. Za možného autora označuje grófa Emanuela Beňovského, brata Mórica, ktorý ho azda aj osobne poznal ešte z Francúzska. ${ }^{42}$

François de Tott poslal aj inú žiadost'. Listom z 22. novembra 1792 sa obrátil priamo na panovníka a požiadal ho o amnestiu. ${ }^{43} \mathrm{~V}$ tomto krátkom, po francúzsky písanom texte sú jeho rodinné zväzky uvedené správne.

Okrem týchto listín sa nám dostal do rúk hárok, na ktorom na jednej strane píše nitriansky archivár o rodine Tóthovcov Palóczimu. Na druhej strane je načrtnutý rodokmeň Tóthovcov Pavla, Juraja, Alberta, Petra II. atd'. a oddelene toto: ,"Tóth Miklós $\rightarrow$ András 1698. III. $26 \rightarrow$ ? Ferencz Franciaországban (sic). “44

Spisy, na ktoré sa odvolával Edgár Palóczi a ktoré by potvrdzovali dátum a miesto narodenia Andreja Tótha (26. marca 1698, Nitra), sa dnes v archíve už nepodarilo nájst'. Tieto dokumenty dokonca ani sám Palóczi nemohol vidiet', lebo píše, že ,stará matrika nitrianskej cirkvi ohl'adon narodení dnes už [pred rokom 1916 - Z. H, F. T.] bohužial nesiaha spät’ pred rok 1700 “. ${ }^{45}$ Naše skúse-

homines antiquis et authenticis jam fati I(nclyti) Comitatus Nittriensis Regestriis inter veros Dominos Nobiles connotati insertique habeantur atque Familiae hujus modi individua in quantum in Gremio I(nclyti) Comitatus hujus actu habitarent verae Nobilitaris Praerogative usu gauderent. Super quibus praesens meum in conformitate gratiosae Inclytae Universitatis eatenus interventae Determinationis extradedi Testimonium. Ex Generali Congregatione Nittriae die 10ma Mensis Maii Anno 1793 continuative celebrata Paulus Rudnyánszky de Dezer (Inclyti) Comitatus Nittriensis Juratus Primarius Vice Notarius m. p. L. S. “ Citované podl'a Palócziho s. 337-338.

42 PALÓCZI, ref. 4, s. 265.

43 PALÓCZI, ref. 4, s. 171-173, 319

44 ŠOA, ref. 39.

45 PALÓCZI, ref. 4, s. 268-269. 
nosti tento fakt len potvrdzujú. Matrika Dolného mesta Nitry je zachovaná od roku 1700, Horného mesta Nitry od roku 1787.

Popri nobilitári sme preštudovali súpis šl'achty miest Horná Nitra a Dolná Nitra na prelome 17. a 18. storočia, ktorý Palóczi nepreštudoval, resp. nevenoval mu pozornost'. Hl'adali sme príslušníkov rodín s priezviskom Tóth vo všetkých možných variantoch. Ako najskorší dátum sme zvolili prvý rok dostupného šl’achtického súpisu, ktorý bol uložený vo fonde oblastného archívu, t. j. 1641. Výsledky sú takéto:

1641: žiadny záznam

1669: žiadny záznam

1677: Michaël Tott

1690: žiadny záznam

1693: Michaël Tot

1693: Michel Tott Horná Nitra

1693: Michaël Tot Horná Nitra

1698: žiadny záznam

1699: žiadny záznam

1705: žiadny záznam

1706: nečitatel'ný záznam

1710: Michaël Thott Horná Nitra

1713: žiadny záznam.

Vidíme, že v tomto období žiadny zeman s menom Mikuláš (Nicolaus atd’.) $\mathrm{v}$ meste nežil.

Pokial' ide o genealógiu rodiny Palóczi spomína aj d’alšie dediny zo slúžnovského okresu Nitra, predovšetkým Horné Krškany a Dolné Krškany. Je pravda, že aj v týchto dvoch dedinách sa nachádzajú Tóthovci, no Mikuláš nie.

Nobilitár Tóth XII. 804 obsahuje dokumenty súvisiace so zemianskymi rodinami s priezviskom Tóth. Spájat' d'alšie spisy s Andrejom a Françoisom, okrem vyššie uvedených, sme však hodnoverne nemohli.

Aby bol náš výskum čo najúplnejší, nahliadli sme ešte do matriky mesta Nitry, ktorú Palóczi neskúmal. Matricula Copulatorum mesta je zachovaná od roku 1692 do roku 1740. Pre nás boli zaujímavé len roky 1692 - 1700, ked'Andrejovi rodičia mohli uzatvorit' sobáš. Neskorší dátum sme vylúčili z toho dôvodu, že Andrej Tóth sa musel narodit' pred rokom 1700, inak by sa v roku 1704 nemohol stat' pážat'om. Prvý historicky overený dôkaz o Andrejovi Tóthovi totiž pochádza od kniežat’a Františka II., ktorý vo svojich memoároch píše, že generál Šimon Forgách mal za páža práve Andreja Tótha. ${ }^{46}$ Tento záznam s určitost'ou dokazuje, že Tóth pochádzal zo zemianskej rodiny, ináč by sa nemohol stat' pážat'om.

46 RÁKÓCZI, Ferenc. Emlékiratok. Budapest: Szépirodalmi Könyvkiadó, 1985, 160 s. ISBN 9631528839. 
Sobášna kniha zahŕňa osem záznamov o Tóthovcoch, samozrejme, nielen urodzeného pôvodu. V týchto zápisoch bol iba raz doslovne spomínaný ženích zemianskeho pôvodu, Martinus Toth, ale meno Mikuláš sa nevyskytlo ani raz. Objavili sa tu však krstné mená ako Michaël alebo Ioannes. ${ }^{47}$

Treba ešte pripomenút', že E. Palóczi preskúmal mnohé regionálne archívy a zemianske armálesy, ktoré sme tu neuvádzali.

Stanovisko autorov by sme teda zhrnuli takto: zemiansky pôvod Andreja Tótha považujeme za dokázaný, $v$ opačnom prípade by sa totiž nemohol stat' pážat'om Šimona Forgácha a nemohol by byt' povýšený do šl'achtického stavu vo Francúzsku. Ku krstnému menu jeho otca sme sa v dokumentoch, ktoré vznikli na prelome 17. a 18. storočia, respektíve na začiatku 18. storočia, nevedeli hodnoverne dopátrat'. To, že Andrej Tóth pochádzal z Nitry, je doložené iba na konci 18. storočia, asi devät'desiat rokov po jeho narodení. V súčasnosti najpresnejším dostupným dôkazom nitrianskeho pôvodu je skutočnost', že sám František Tóth oslovil túto stolicu. To, že sa podpísal ako Andrej Tóth, však zvyšuje neistotu okolo tohto dokumentu. Treba zdôraznit' aj to, že jedine tento dokument potvrdzuje všeobecne uznanú tézu, že jeho starý otec sa volal Mikuláš. Na druhej strane je nutné zohl'adnit' aj to, že barón sa nesnažil, respektíve nie sú na to dôkazy, že by oslovil alebo hl'adal svojich príbuzných v stolici.

Náš záver je teda takýto: Andrej Tóth nemohol byt' obyvatel'om mesta Nitry dlhšiu dobu, ale len približne jedno desat'ročie na prelome storočia. Prežil tam len roky svojho raného detstva a neskôr sa do Nitry už nikdy nevrátil. To, že predsa mal vzt'ah k mestu Nitre, či k Nitrianskej stolici, môžeme považovat' za vel'mi pravdepodobné.

Viacerí súčasní slovenskí historici svorne zdiel'ajú názor, že Andrej Tóth bol Slovák, a to na základe priezviska. „Pomenovaním Tót, Tóth sa v starej mad'arčine označoval Slovák či Slovan vôbec. Mnohé šlachtické rody sa však časom pomad'arčili, resp. vyznávali štátoprávnu ideologiu hungarizmu... Takými boli aj Tóthovci z Nitrianskej stolice. "48 Rovnaké stanovisko vyslovuje aj Miroslav Daniš: „Barónovo priezvisko Toth, ktoré v preklade znamená Slovák, nás nabáda hladat' barónove korene $v$ slovenskom prostredí. “49 Podl'a nášho názoru pripísat' konkrétnu etnicitu niekomu, navyše šlachticovi v Uhorsku na prelome 17. a 18. storočia, nie je správne. Pravdou je, že Françios de Tott sa už narodil vo Francúzsku a so slovenským jazykom sa už nikdy nedostal do styku. Jeho otec Andrej sa síce narodil v geografickej oblasti, kde hlavným dorozumievacím

47 HORBULÁK, ref. 1, s. 126-144.

48 SEGEŠ, ref. 6, s. 21.

49 DANIŠ, Miroslav. Slovensko, husári a cárovná. Bratislava: Stimul, 1993, s. 91. ISBN 8085697127. 
jazykom bola slovenčina, avšak tento región opustil už v detstve, ked' sa dostal do tábora kniežat’a Rákociho.

Nakoniec ešte treba venovat' pár slov písaniu priezvisk. Priezvisko baróna v medzinárodnej odbornej literatúre je písané v podobe „François de Tott“. Túto formu používal aj sám barón. $\mathrm{V}$ prípade jeho otca najčastejšou podobou písania priezviska je „Tóth“, hoci vo Francúzsku ho už oslovovali ako „Totte“.$^{50}$ Jeho mladšieho syna vždy spomínajú pod menom „André de Tott“. Čo sa týka Františka, v mad'arských textoch, ktoré vznikli v priebehu 19. storočia sa postupne udomácnila forma „Tóth Ferenc“. Révai Nagy Lexikona však uvádza obe verzie: „Tóth Ferenc (François, Baron de Tott) “. ${ }^{51}$ Podobné kompromisné riešenie zvolila najnovšia mad’arská encyklopédia Magyar Nagylexikon: , Tóth Ferenc, br.; Tott" ${ }^{52} \mathrm{~V}$ slovenských dielach sa vyskytuje forma „František Tóth“. ${ }^{53} \mathrm{Na}$ náhrobnom kameni baróna je jeho meno napísané takto: „BARON FRANZ VON TÓTH“. V tejto štúdii sme uprednostňovali najčastejšiu použivanú francúzsku podobu písania mena, ktorú používal aj sám barón.

$* * *$

Spomienky Françoisa de Totta vzbudili vel'ký záujem ihned' po vydaní. Ešte pred koncom 18. storočia ich preložili do nemčiny, ${ }^{54}$ dánčiny, ${ }_{55}^{5}$ švédčiny ${ }^{56}$ a angličtiny. ${ }^{57} \mathrm{~V}$ súčasnosti zoznam úplných vydaní sa rozšíril o mad’arčinu a turečti-

50 ZACHAR, ref. 38, s. 223, 226, 228.

51 Révai Nagy Lexikona, zv. 18, 1925, s. 382-383.

52 Magyar Nagylexikon, zv. 17, 2003, s. 609.

53 Pozri pozn. č. 1,2 a 3.

54 Des Barons von Tott Denkwürdigkeiten und Nachrichten von Türken und Tatarn (3 vol.). Elbing, 1786-1787; Herrn Baron von Tott's Nachrichten von den Türken und Tataren mit Herrn von Peyssonnel's Verbesserungen und Zusätzen (2 vol.). Frankfurt 1787-88; Herrn Baron von Tott's Nachrichten von den Türken und Tartaren mit Herrn von Peyssonnel's Verbesserungen und Zusätzen (2 vol.). Vienne 1788; Totts Denkwürdigkeiten über die Türken und Tartarn (3. vol.). Berlin 1794.

55 Efterretninger som Tyrkerne og Tartarerne. Oversat af det Franske ved Morten Hallager (1-2. Deel). Copenhague 1786.

56 Strödda underrättelser om Turkarne och Tartarne, samlade af Baron Tott. Upsala 1800.

57 Memoires of the Baron de Tott, on the Turks and the Tartars. Translated from French by an English gentleman at Paris, under the immediate inspection of the Baron... (2 vol.). London 1785; Memoirs of the Baron de Tott, on the Turks and the Tartars. Translated from French by an English gentleman at Paris, under the immediate inspection of the Baron... (3 vol.). Dublin 1785; Memoirs of Baron de Tott. Containing the state of the Turkish Empire and the Crimea, during the war with Russia. With numerous anecdotes, facts, and observations, on the manners and costums of the Turks and Tartars... To which are subjoined the strictures of M. de Peyssonnel (2 vol.). London 1786. 
nu, ${ }^{58}$ ale aj pôvodný francúzsky text vydali viackrát. ${ }^{59} \mathrm{~V}$ niektorých prípadoch sa prekladala len určitá čast' diela, ktorá mohla zaujat' miestne obyvatel'stvo. ${ }^{60}$ Jedno z najúplnejších vydaní, ktoré vyšlo s úvodnou štúdiou Ferenca Tótha roku 1785 v Maestrichte, opätovne vydalo roku 2004 parížske vydavatel'stvo Honoré Champion.

Autor túto prácu napísal v štýle spomienok (mémoires), teda v žánri, ktorý bol v 18. storočí pomerne rozšírený. Text diela je na jednej strane lineárnym opisom života autora, na strane druhej sa skladá $\mathrm{z}$ heterogénnych textových fragmentov. Na stránkach Spomienok sa dočítame o významných periódach Tottovho života, rozdelených do štyroch pomerne nesúviacich častí a úvodného komentára. Okolnosti vzniku textu sa ešte nepodarilo úplne objasnit'. Je však vel'mi pravdepodobné, že jednotlivé časti knihy vznikli v štyroch rôznych obdobiach a autor ich pôvodne chcel publikovat' samostatne.

Najoriginálnejšou čast'ou práce je Predslov (Discours préliminaire), ktorý uvádza autorove Spomienky. Je to akási historická a filozofická úvaha o podstate civilizácie a l’udstva, na strane druhej bojovný politický pamflet proti Montesquieuovej teórii klímy. Na rozdiel od autora diela Duch zákonov Tott pred prírodnými (klimatickými) silami hlása primát duchovných (morálnych) síl (forces morales). Uznáva iba jednu výnimku: v horských oblastiach prírodné sily zostávajú dominantné pre rozvoj spoločnosti. Na základe svojich skúseností nadobudnutých počas cestovania po Blízkom východe usudzuje, že despotizmu Osmanskej ríše úspešne odolávali len také národy, ako sú Kurdi a Drúzovia. ${ }^{61}$ Idea východného despotizmu je, mimochodom, pravidelne sa opakujúcim motívom Tottovho diela. Táto politicko-filozofická línia spája jednotlivé časti a je determinujúcim prvkom Spomienok. ${ }^{62}$ Myšlienka tohto politického myslenia má

58 TOTT, François baron de. Türkler ve Tatarlara dair hatiralar, Topaloğlu. Ed. M. Fatih. Ankara: Kesit Tanitim Ltd. Şti., 2004. ISBN 9789758971121.

59 Mémoires du baron de Tott sur les Turcs et les Tartares (2 vol.). Amsterdam 1784-1785; Mémoires du baron de Tott sur les Turcs et les Tartares ( 2 vol. in $4^{\circ}$ avec des planches). Amsterdam 1785; Mémoires du baron de Tott sur les Turcs et les Tartares (2 vol. + Lettre de M. le Baron de Tott à Ruffin. Réponse de M. Ruffin. Observations de M. Ruffin sur la critique des Mémoires de M. le Baron de Tott par M. Peysonnel.). Amsterdam 1785; Mémoires du baron de Tott sur les Turcs et les Tartares (3 vol.). Paris, 1785; Mémoires du baron de Tott sur les Turcs et les Tartares (4 vol.). Maestricht, 1785; Mémoires du baron de Tott sur les Turcs et les Tartares (3 vol.). Amsterdam 1788.

60 Zapisky barona de Totta o tatarskom našestviji 1769 goda. Kijiv: Kijevskaja starina, 1883, s. 138-198; BANNER, Benedek. Báró Tóth Ferenc születésének kétszázéves évfordulójára 1733-1793. Memoárjának Egyiptomot tárgyaló része. Békéscsaba 1933.

61 Discours préliminaire, s. XIV-XV.

62 Podl'a Numa Broc dielo má vyslovene politický charakter. Pozri BROC, Numa. La géographie des philosophes. Géographes et voyageurs français au $18^{e}$ siècle (Thèse publiée). Lille 1972, 
hlboké korene a počas 18 . storočia prešla mnohými zmenami. ${ }^{63}$ Henry Laurens jednoznačne dokázal, že vydanie Tottových Memoárov predstavuje obrat vo filozofickej diskusii o východnom despotizme. ${ }^{64}$

Autor odmieta aj druhú populárnu prácu, ktorá výrazne ovplyvňovala vtedajšiu verejnost' - Listy Milady Montague, a to aj napriek tomu, že tieto listy z určitého pohl'adu boli pre neho vzorom. ${ }^{65}$ Manželka anglického vel'vyslanca v Konštantínopole prvýkrát ponúkla čitatel'om subjektívny pohl'ad na háremy a kúpele, čo Európan v tom čase na vlastné oči vidiet' nemohol. Jej posmrtne vydaná práca sa stala čoskoro populárnou. V predslove Spomienok Tott predstavuje sám seba, v porovnaní s anglickou dámou, ako vysokokvalifikovaného odborníka. ${ }^{66}$ Jeho najvyšším ciel'om je predstavit' čitatel'om svoj denník, ktorý vznikol počas pobytu v Oriente. ${ }^{67}$

V prvej časti Spomienok autor rozpráva o svojom prvom pobyte (1755-1763) v Osmanskej ríši. Formou krátkych, niekol'kostranových textov zaradanených do vol'ného chronologického radu opisuje osmanskú spoločnost', jej obyčaje a zvyky. V celom texte nájdeme len dva odkazy na čas, autor prezradí len dátum príchodu a odchodu. Medzi týmito opornými bodmi čas plynie nekonečne. Tento čas je časom despotizmu, ktorý však má vlastnú chronológiu: ,,pre despotizmom podmaneného človeka staré strasti zmiernia len nové strasti a pripomeniem, ak sa v Konštantínopole niekoho spýtajú na jeho vek, ten vždy uvedie rok vypukutia volajakého moru, hladomoru, povstania či požiaru ". ${ }^{68}$

Tott tieto anekdotické a analyzujúce texty charakterizujúce osmanský svet pravdepodobne napísal po návrate do Francúzska v roku 1763. Vzhl'adom na to, že mal literárne ambície, kratšie texty pripravoval už počas prvého konštantínopolského pobytu. Úspech vydania listov Milady Montague ešte viac ovplyvnili jeho plány v oblasti literatúry. Svoje rukopisy rozposielal mnohým významným osobám versailleského dvora, najmä svojim vplyvným priatel’om, medzi nimi i grófovi Vergennesovi. Knieža Choiseul, čítajúc spisy učňa diplomacie, mu ponúkol post $\mathrm{v}$ Kolíne, ale nakoniec $\mathrm{k}$ tomu nedošlo. ${ }^{69}$ Mladý orientalista mal

p. 500.

63 Pozri GROSRICHARD, Alain. Structure du sérail, La fiction du despotisme asiatique dans l'Occident classique. Paris: Seuil, 1979. ISBN 2020050560.

64 LAURENS, ref. 30, s. 63-73.

65 MONTAGU, Wortley Mary. Letters. London 1906. Prvé vydanie je z r. 1763. Tott v jednom d’alšom vydaní zverejnili svoje kritické poznámky.

66 Mémoires I, s. XXI.

67 Ref 66, s. XXII.

68 Ref 66, s. 100-101.

69 Archives Diplomatiques (AD, Archív Ministerstva zahraničných vecí Francúzska, La Courneuve) dossiers du Personnel première série vol. 67 fol. 10 . 
zrejme aj vážnejšie publikačné plány. Svedčí o tom list grófa Vergennesa z 20. decembra 1764, v ktorom ho nabáda k ostražitosti:

„Už ste dosiahli, aby vašu prácu ocenili uznaním. Dostalo sa ku mne, Pane, že ste predstavili niekol'ko písomností o Turecku, čo sa stretlo s pozitívnym ohlasom. To ma neprekvapuje, ved' predtým ako ste odcestovali aj mne ste už ukázali niekol'ko exemplárov, ktoré dostatočne svedčia o vážnosti vašich výskumov. Ale aj to sa hovorí, že inklinujete $k$ tomu, aby ste ich dali vytlačit'. Ak moja rada pre vás niečo znamená, odporúčal by som vám, aby ste vzdorovali tomuto pokušeniu, akokol'vek sú podmienky zvádzajúce. Obcenstvo nehodnotí vždy zhovievavo, málokedy odpustí naše omyly [...] Je pravdou, že vel'ké úspechy listov Milady Montague u našich žurnalistov vás povzbudujú, ale všetkým britským tovarom preukazujeme obdiv, ba až nadšenie. "70

Tott poslal svoje príspevky aj Voltairovi. Filozof sa o tom zmieňuje v liste adresovanom markízovi Philippovi Antoinovi de Claris Florian nasledujúcim spôsobom:

„Prosím, povedzte mi, môj Turek, že či už Vám tento turecký Tott poslal svoje diela o tureckej správe. Vás nenahnevá, že Atény a Korint sa nachádzajú pod nadvládou akéhosi bašu či pašu? "71

Voltaire vo svojom liste z 23. apríla 1767 pod'akoval Tottovi za zaslané písomnosti týkajúce sa tureckých záležitostí. Úryvok z jeho listu nám predstaví iného filozofa, než ako ho poznáme:

„Myslel som si, že sa od Vás nauč́m vel'a, ale to som vôbec nepredpokladal, že sa budem tak zabávat' na Turkoch. Vy ste dokázali, že humor existuje v každom štáte. $Z$ celého svojho srdca d'akujem za anekdoty, ale darmo bolo radostné všetko čitat', čo Vy širite o obrezaných Tatároch, nad'alej ma hnevá, že panujú na územi Orfea a Homéra. Nemám rád taký l'ud, ktorý vie len ničit' a je nepriatel'om umenia." "72

Počas dvadsatich rokov, kým sa text dostal do tlače, s vel'kou pravdepodobnost'ou prešiel aj obsahovými zmenami. Výrazná kritika východného despotizmu

70 Archives de la Famille de Vergennes (archív rodiny Vergennesovcov, Marly-le-Roy), list Vergennesa Tottovi (Konštantínopol, 20. decembra 1764). Chceli by sme vyjadrit' vd'aku p. Pierrovi de Tugny-Vergennes, že nám umožnil výskum v rodinnom archíve.

71 V originály: „Dites-moi, je vous prie, mon Turc, si ce Turc de Tott vous a donné de bons mémoires sur le gouvernement de ses Turcs. N'êtes-vous pas bien fâché qu'Athènes et Corinthe soient sous les lois d'un bacha ou d'un pacha. "VOLTAIRE. Correpondance tome VIII. Paris: Gallimard, 1987, s. 1088. ISBN 9782070111121; TÓTH Ferenc. Voltaire és egy magyar származású francia diplomata irodalmi kapcsolatai. In HORN, Ildikó et al. (ed.). Müvészet és mesterség. Tisztelgö kötet R. Várkonyi Ágnes emlékére. I. zv. Budapest: L'Harmattan, 2016, s. 587-605. ISBN 9789632364971. Používanie slova Turek pre adresáta listu aj pre Totta u Voltaira je prejavom turkománie $\mathrm{v}$ danej dobe.

72 VOLTAIRE, ref. 71, s. 1100. 
sa mohla dostat' do diela taktiež až neskôr. Počas svojho prvého diplomatického pobytu, stojac pred sl'ubnou kariérou, si Tott svoje myšlienky ešte zapisoval s vel'kým entuziazmom.

Druhá kniha Tottových Spomienok je venovaná diplomatickej ceste ku krymským Tatárom $\left(1767\right.$ - 1769). ${ }^{73} \mathrm{Na}$ začiatku tohto zväzku stručne spomína úmrtie svojho otca a potom sa venuje opisu dvora krymského chána, avšak neprezrádza ciel' svojej misie. Z pohl'adu vzniku textu je dôležité, že popri diplomatických povinnostiach mal autor aj vedecko-zberatel'ské poslanie. Knieža Choiseul na konci inštrukcie vyslania píše:

„Zozbierajte všetky informácie o takých veciach, ktoré môžu zaujímat' či zaujat'král'a - o mravoch, zvykoch a verejnej správe Tatárov, taktiež o kvalite pôdy, o umiestneni prístavov, miest a pevností, teda všetko, čo by pre nás mohlo byt zaujímavé z krajiny, o ktorej máme len neurčité a povrchné vedomosti. "74

Nevieme presne, $\mathrm{s}$ akým výsledkom sa Tottovi podarilo splnit' túto čast' misie, ale jeho osobné skúsenosti iste mali vel'ký vplyv aj na nami analyzovaný text. V Archíve francúzskeho ministerstva zahraničných vecí sa nachádza rukopis opisujúci agrárny zemepis krymského polostrova (Description physique de la Crimée, 1786), ktorý pripisujú Tottovi. ${ }^{75}$ Či bol autorom naozaj on, dnes už nevieme s určitost'ou dokázat'. Faktom je, že sa o tom v rukopise nenachádza žiadny odkaz a samotný text sa značne líši od textu druhej časti Memoárov. Na strane druhej rukopis vznikol roku 1786, teda rok po prvom vydaní Spomienok. S vel'kou pravdepodobnost'ou však môžeme konštatovat', že neexistuje žiadna súvislost' medzi týmito dvoma textami.

Druhý zväzok sa snaží detailne predstavit' Tatárov a podat' ich objektívny a vedecký opis. Nasvedčuje tomu aj samotný názov Memoárov ako celku. V tejto ranej fáze orientalistiky Európania o Tatároch takmer nič nevedeli. Podl'a Josepha von Hammer-Purgstalla Tottova kniha patrila v 19. storočí medzi devät' najvýznamnejších prameňov o Tatároch. ${ }^{76}$ Hammer-Purgstall tvrdil, že autor opisuje Nogajcov so zvedavost'ou osvieteného človeka. V jeho vetách sa ani v náznakoch nenachádza nadradenost' Európana. $V$ diele opisuje aj prírodné bohatstvo územia obývaného Tatármi. Vieme, že svoju kariéru diplomata sa snažil

73 TÓTH, Ferenc. La mission du baron de Tott en Crimée. In Archivum Ottomanicum 20. Ed. György Hazai. Wiesbaden 2002, s. 131-165. ISSN 0378-2808.

74 Bibliothèque Municipale de Versailles (Mestká knižnica vo Versaillese), Baron François de Tott L. 278 Mission de Crimée en 1767 Tome I, Mémoire pour servir d'instruction au sieur baron de Tott chevalier de l'ordre militaire de Saint Louis et mestre de champ de cavalerie, envoyé par le Roy vers Aslan Gueray Kan de Crimée, fol. 21.

75 AD, série Mémoires et documents - Russie (1735-1759) Tome 18. Description physique de la Crimée, le 4 novembre 1786, (par le baron de Tott?; un seul document de 98 folios doubles).

76 HAMMER-PURGSTALL, Joseph von. Geschichte der Chane der Krim unter osmanischen Herrschaft. Wien: K. K. Hof- und Staatsdruckerei, 1856, s. 15-16. 
umocnit' vypracovaním plánu o čiernomorskom obchode, ktorý predložil kniežat'u Choiseulovi. ${ }^{77} \mathrm{Z}$ toho vyplýva, že parciálnou úlohou barónovej krymskej misie bolo aj zmapovanie obchodných príležitostí v oblasti jeho pôsobenia ako konzula. ${ }^{78}$ Barón Tott zohral významnú úlohu aj ako sprostredkovatel' kultúr. Nielenže oboznámil chána s najvýznamnejšími dielami francúzskej literatúry, ${ }^{79}$ ale vd’aka svojim prírodovedeckým znalostiam predviedol Tatárom elektrinu, za čo si vyslúžil prezývku kúzelník a čarodejník. Na sklonku svojho života v Tatzmannsdorfe konal, ako už bolo naznačené, podobne. ${ }^{80}$

Historický prínos tejto časti Spomienok je vel'ký, ked’že nám umožňuje urobit' si predstavu o mnohých politických a vojenských udalostiach. Barón opisuje ako rokovali predstavitelia pol'skej konfederácie s Tatármi, no zamlčuje tajné rozhovory. Taktiež nám nič nepovie o tom, čo si písal s bratom, ktorý sa v tom čase zdržiaval v Sankt Peteburgu. Jeho brat André pôsobil taktiež v službách francúzskej diplomacie a vykonával príkazy francúzskeho vel'vyslanca Rossignola až do 20. decembra 1768, kým ho z Ruska nevyhostili. ${ }^{81}$

Tretia čast' Memoráov sa začína opisom druhého, najplodnejšieho obdobia, ktoré Tott strávil v Konšatntínopole. ${ }^{82}$ Podrobne popisuje problémy, s ktorými sa stretol a ktorým musel vzdorovat', pričom vždy zdôrazňuje svoje osobné zásluhy. Pochopitel'ne, aj tu sa zmieňuje o poverčivom spôsobe vedenia vojny Turkami. Nasledujúca pasáž názorne opisuje turecký spôsob boja: „Nadutú nevedomost' generálov sprevádzala hlúpa namyslenost' dôstojnikov. Turci prichádzali na bojisko s vel'kým počtom diel, ale takmer všetky boli zle vystrojené a rovnako zle ich použivali. Ked'ich nepriatel'ská pal'ba zasiahla, odpovedali Rusom nadávkami. Boli hrdí na silu svojho delostrelectva a hovorili, že Rusi sa nemôžu k nim približit. No ak by sa skončila delostrelecká pal'ba a na rad by prišli ručné zbrane, neveriaci by uvideli ako bojujú so svojimi šablami pravoverní. Títo fanatickí hlupáci vyčitali Rusom aj to, že sa opovážili útočit'v čase ramadánu. "83

77 O tejto téme pozri francúzskeho konzula v Smirne: PEYSSONNEL, Claude-Charles de. Traité sur le commerce de la mer Noire (2 vol.). Paris 1787.

78 Bibliothèque Municipale de Versailles, Baron François de Tott L. 278 Mission de Crimée en 1767 Tome I, Mémoire pour servir d'instruction au sieur baron de Tott chevalier de l'ordre militaire de Saint Louis et mestre de champ de cavalerie, envoyé par le Roy vers Aslan Gueray Kan de Crimée, fol. 20-21.

79 Mémoires II, s. 119-120.

80 Bibliothèque Municipale de Versailles, Baron François de Tott, L. 278, Mission de Crimée en 1767, s. 125-126.

81 CADN, Saint-Priest, ref. 18, 232 s. 8-9.

82 Bližšie pozri AKSAN, Virginia. Breaking the Spell of the Baron de Tott: Reframing the Question of Military Reform in the Ottoman Empire, 1760-1830. In The International History Review, 2002, roč. 24, č. 2, s. 253-277. ISSN 07075332.

83 Mémoires III, s. 8-9. 
Na návrh francúzskeho konštantínopolského vel’vyslanca grófa Saint-Priest, v júli 1770 reîs effendi (turecký minister zahraničných vecí) vyslal baróna Totta, aby sa postaral o posilnenie obrany dardanelských úžin proti lodiam admirála Orlova ${ }^{84}$ Po príchode zistil, že tamojšie opevnenie sa nachádza v značne zanedbanom stave a bojaschopnost' obrancov bola vel'mi nízka. ${ }^{85}$ To všetko vyvrcholilo v hlúposti vojenského vedenia, čo autor Memoárov pripisoval prirodzenému vplyvu východného despotizmu. V diele nechýbajú ani anekdotické časti, ktoré ešte reálnejšie opisujú tragickost' situácie. Ako príklad by sa dala uviest' udalost', ked' kvôli škrekotu papagája takmer vypuklo masové vraždenie. ${ }^{86}$

Tott referuje aj o bitke pri Česme, ktorú opísal na základe rozprávania očitého svedka Džezajirli Gázi Hassán pašu, ktorý sa neskôr stal výzamným reformátorom osmanských námorných síl. ${ }^{87}$ Tott sa vtedy vyznamenal ako organizátor obrany úžin. Okrem neho tam na žiadost' francúzkeho vel'vyslanca bol ešte prítomný aj barón Pontecoulant, neskorší minister z obdobia revolúcie. Listy vel'vyslanca dokladajú, že na stavbách pracovali aj mnohí d’alší Francúzi. ${ }^{88}$

Posledná čast' Memoárov opisuje Tottovu diplomatickú misiu, a to kontrolnú okružnú cestu po francúzskych obchodných kolóniách pozdíž Levanty a Barbarie, východného pobrežia stredomorskej oblasti (1777 - 1778).

Táto cesta bola poslednou významnou obchodnou, kolonizačnou, ale v neposlednom rade aj vedeckou akciou ancien régim na Blízkom východe. Výber Totta sa nestretol so všeobecným súhlasom na versailleskom dvore. Gróf Saint-Priest, francúzsky vel'vyslanec $\mathrm{v}$ Konštantínopole namietal, že úlohu kontroly obchodnej administrácie zveria do rúk človeku, ktorý mu bol dlhé roky podriadený. ${ }^{89}$ Nie je preto náhoda, že Saint-Priest vol'bu považoval za prejav nepriazne grófa Vergennesa, štátneho tajomníka zahraničných vecí. Je zaujímavé, že Vergennes nesúhlasil s tajnou čast'ou Tottovej misie, ktorá smerovala k možnému obsadeniu Egypta. Podl'a neho sa mala udržat' integrita Osmanskej ríše, ktorá bola v priatel'skom vzt'ahu s Francúzskom.

Text štvrtej časti, písaný podobným denníkovým štýlom ako predchádzajúce strany, nám podáva detailný opis cesty cez more, ktorá bola nebezpečná. Centrom záujmu tejto časti diela je Egypt. V tomto období totiž značne vzrástol význam tejto provincie Osmanského impéria. Navyše, ako už bolo naznačené, Tott mal vykonat' prieskum podmienok na prípadnú okupáciu. Svoj referát neskôr

84 CADN, Saint-Priest, ref. 18, 232 s. 407.

85 Ref. 83, s. 31-32.

86 Ref. 83, s. 16-17.

87 SHAW, Ezel Kural - HEYWOOD, Colin J. English and Continental Views of the Ottoman Empire, 1500-1800. Los Angeles: University of California, 1972, s. 9. ISBN 9789992095812.

88 CADN, Saint-Priest, ref. 18, 232 s. 438-439.

89 SAINT-PRIEST, C. de. Mémoires tome I. Paris 1929, s. 160. 
poslal aj královi. ${ }^{90}$ Pri porovnaní textu tejto správy s textom Memoárov pozorný čitatel' nájde zaujímavú paralelu. Určité časti referátu sa do tlačenej verzie Spomienok prevzali doslovne, niektoré d’alšie s menšími modifikáciami. Na základe výskumu Christopha Farnauda poznáme aj podiely týchto častí. Takmer polovica (44 \%) tajnej správy zostala nemenná, d’alšia štvrtina (24 \%) prešla menšími zmenami, ale dokázatel'ne pochádza z rukopisu referátu. ${ }^{91}$ Ked’že vo vládnych kruhoch sa myšlienky referátu nepresadili, javí sa ako jednoznačné, že autor ho využil vo vlastnom diele. Podl'a slov Henryho Laurensa sa táto kniha stala jedným z diel, ktoré najviac ovplyvnili verejnú mienku svojej doby. ${ }^{92}$

Autor s preň typickým anekdotickým spôsobom zapracoval zlomky textov do svojho diela, a tak nám predstavuje Egypt. ${ }^{93}$ Opis má geografický, hospodársky, antropologický a ekonomický ráz. Pomocou neho sa snaží vykreslit’ „,morálny obraz“" (tableau des mœeurs) Egypt'anov. Tento portrét nie je pre obyvatel'ov Egypta príliš priaznivý. Vidíme l'udí slabých a poverčivých. ${ }^{94}$ Tott sa samozrejme o obsadení Egypta v Spomienkach nezmieňuje, avšak nájdeme v nich odkazy na alternatívnu budúcnost' tejto bohatej provincie Osmanskej ríše. ${ }^{95}$

Pri zaznamenávaní svojej posledenej cesty sa často venoval opisu kultúrnych pamiatok. Takto predbiehal expedíciu vedcov Napoleona Bonaparta, ktorej hlavnou úlohou bolo vypracovat' dielo Opis Egypta (Description de l'Egypte). Podl'a svedectva Spomienok Tott bol vášnivý vedec a zberatel'. Podl'a anonymného spolucestovatel'a sa mu podarilo nazbierat' vel'a antických pamiatok. ${ }^{96}$

Dnes sa jediný známy exemplár rukopisu diela nachádza v knižnici Bibliothèque de l'École Supérieure de Guerre v Paríži. Ozdobne zviazaný rukopis Mémoires du baron de Tott kedysi patril do osobného majetku L'udovíta XV. ${ }^{97}$

90 TÓTH, Ferenc. La double mission du baron de Tott à la fin de 1'ancien régime. In Africa, 2002, roč. 57, č. 2, s. 147-178. ISSN 0001-9747. Kópia Tottovho hlásenia je dostupná vo francúzskom Vojenskom archíve (Service Historique de la Défense, série MR Egypte - Reconnaissances jusqu'en 1830; Examen de 1'etat physique et politique de 1'Empire Ottoman et des vues qu'il determine relativement à la France). Porov. CHARLES-ROUX, François. Le projet français de conquête de l'Égypte sous le règne de Louis XVI. Le Caire 1929.

91 FARNAUD, Christophe. Culture et politique: la mission secrète du baron de Tott au Levant (1776-1779). Mémoire de maîtrise préparé sous la direction de Jean Meyer. Paris IV: Université de Paris-Sorbonne, 1988, s. 136.

92 LAURENS, ref. 30, s. 63.

93 Významná čast' štvrtej časti Spomienok (s. 17-61.) je takmer úplne totožná s rukopisom kapitoly s názvom L'Etat actuel de l'Egypte (s. 124-160) spomínaného referátu.

94 Mémoires IV, s. 60-61.

95 Ref. 94, s. 48-49.

96 Ref. 94, s. 89.

97 Bibliothèque de 1‘École Supérieure de Guerre, série MSS 54-55. Mémoires du baron de Tott. Pozri jeho detailný opis: Catalogue générale des manuscrits des bibliothèques publiques de France, Bibliothèques de la guerre. Paris 1911. 
Pri skúmaní rukopisu sa zistilo, že okrem menších detailov je totožný s textom vydaného diela. Bohužial', iné exempláre Memoárov sme nemali možnost' analyzovat' a o prameňoch vymenovaných autorom taktiež máme vel'mi málo informácií.

Je potrebné pripomenút', že pri vydaní Memoárov barón de Tott už bol známou osobou. To čiastočne vysvetl'uje výrazný úspech diela. Podl'a Henryho Laurens počas dvoch rokov Spomienky vyšli v piatich francúzskych vydaniach, preto dielo môžeme označit' v dnešnom ponímaní za bestseller. ${ }^{98}$

Kritika čoskoro objavila túto knihu a vznikla búrlivá diskusia. Prvá analýza pochádza z pera švajčiarskeho publicistu Jacquesa Malleta du Pana. Jeho recenziu uverejnil Mercure de France 4. decembra 1784. ${ }^{99}$ Po stručnom politickom rozbore diela spochybnil autorov neagtívny pohl'ad na Osmanskú ríšu. Du Pan venoval pozornost' takmer všetkým významným momentom diela: situácii žien a otrokov, ničivej kritike despotizmu atd'. Všímol si aj ostrú dištinkciu medzi Turkami a Tatármi, čo ironicky opísal takto:

„S rozumom unaveným z mnohých absurdit a nespočetných poburujúcich javov, z čoho aj duša trpí, sa konečne dostaneme do oblasti pôsobenia takého národa, ktorý sme v našich predsudkoch dlho chápali ako l’udožrútsky. Konečne si vydýchneme, ked' pomocou nášho autora, ktorý opisuje mravy, správu a výpravy sa dostaneme k územiu tatárskych hord. "100

Jednoznačná politická charakterisktika diela zákonite so sebou priniesla aj rôzne strety. Jedna $\mathrm{z}$ najtvrdších literárnych kritík diela, ale predovšetkým jeho autora, pochádza z pera Claude-Charlesa de Peyssonnela (1727 - 1790). Práca s názvom Lettre de M. de Peyssonnel, contenant quelques observations relatives aux mémoires qui ont paru sous le nom de M. le baron de Tott vyšla roku 1785 v Amsterdame. Peyssonnel už v názve svojho kritického diela spochybnil autorstvo Totta. ${ }^{101}$ Jeho kritika smerovala predovšetkým k Tottom neustále spomínanému „východnému despotizmu“. Diskusia o tomto pojme patrí medzi hlavné spoločenské a filozofické debaty vtedajšej doby. ${ }^{102}$ Peyssonnel sa snažil obhájit' turecké súdnictvo, ktoré podl'a neho bolo dokonalejšie ako európske ${ }^{103}$ a pridal sa $\mathrm{k}$ táboru tých publicistov, ktorí odmietali existenciu východného despotiz-

98 LAURENS, ref. 30, s. 63.

99 Mercure de France, du 4 décembre 1784. s. 152-179.

100 Ref. 99, s. 171-172.

101 Lettre de M. de Peyssonnel, Ancien Consul-Général à Smyrne, ci-devant Consul de Sa Majesté auprès du Khan des Tartares, à M. le Marquis de N... Contenant quelques Observations relatives aux Mémoires qui ont paru sous le nom de M. le Baron de Tott. Amsterdam 1785, s. 5.

102 Pozri LAURENS, ref. 30.

103 LAURENS, ref. 30, s. 47-48. 
mu. ${ }^{104}$ Barón Tott odpovedal diplomatickým spôsobom. Požiadal svojho bývalého dragomana, tlmočníka Pierra Ruffina, neskoršie významného orientalistu, aby napísal nejakú pôsobivú odpoved'. Ruffin dobre poznal týchto dvoch starších diplomatov, Totta i Peyssonnela. Dostal sa tak do chúlostivej situácie, a pokúsil sa z nej výjst's nejakou teóriou, v ktorej by dal za pravdu obom stranám. Vo svojej odpovedi sa snažil zosúladit' dva protichodné názory: východný despotizmus de facto existuje, a tak posilnil Tottove argumenty, ale zároveň poznamenal, že de iure despotizmus nie je, ked'že osmanské súdnictvo prostredníctvom inštitúcie ulemov disponuje širokým ochranným zborom. ${ }^{105}$

Peyssonnel podrobil kritike Tottovo dielo aj v d’alšej práci, ktorá vyšla pod názvom Examen du livre intitulé „Considérations sur la guerre actuelle des Turcs " par M. de Volney v Amsterdame roku 1788. Antipatia je viditel'ná na viacerých úrovniach. Prejavila sa v odbornej nežičlivosti a v kariérizme, lebo obaja protagonisti diskusie pôsobili v službách francúzskej diplomacie a obidvaja mali značné skúsenosti v osmanských záležitostiach, ale budúcnost' Osmanskej ríše si predstavovali rôzne. Ich odborná roztržka dosiahla najvyššiu úroveň, ked' Tott počas okružnej revíznej cesty v rokoch 1777 - 1778 zamietol administratívne opatrenia konzula v Smirne, ktorým bol v tom čase práve Peyssonnel. Peyssonnela hned' na to odvolali spät' do Francúzska. ${ }^{106}$

Údaje o čítanosti Memoárov sú k dispozícii. Medzi najznámejšich čitatel'ov radíme král'ovskú rodinu, orientalistu Volneyho, revolucionára Brissota či mladého Napoleona Bonaparta. ${ }^{107}$ Dielo baróna Totta sa čoskoro stalo dôležitou príručnou literatúrou, v ktorej často listovali historici, geografi, orientalisti

104 Základom „diskusie o východnom despotizme“ medzi filozofmi, literátmi a cestovatel’mi bolo, že vyzdvihovali všemohúcnost' panovníka, úplnú poddanost' spoločnosti, neprítomnost' obmedzujúcich síl (stavy) vládcu a slabost' zákonodarnej i súdnej moci. Hlavnou čast'ou diskusie bol pôvod východného despotizmu. Niektorí, ako napríklad Montesquieu, ho pripisovali vplyvu teplého podnebia (klimatická teória), podl’a iných ho zapríčinil spoločenský vývoj. Taký názor zdiel'al aj Tott.

105 „Obervations de M. Ruffin sur la critique des Mémoires de M. le Baron de Tott par M. Peyssonel. " Mémoires du baron de Tott sur les Turcs et les Tartares tome II. Amsterdam 1785. (Appendice) s. 22-23.

106 Archives Nationales (Národná knižnica, Paríž), série Affaires Étrangères, série B III 15 fol. 19.

107 Exempláre členov král’ovskej rodiny sú v s účasnosti uložené v la Bibliothèque Nationale de France. Pozri Ministère de l'Éducation Nationale: Catalogue général des livres imprimés de la Bibliothèque Nationale Tome CXCII. Paris 1965, s. 98-99. O prečítaných dielach Volneyho, Bonaparta a Brissota pozri VOLNEY, Constantin-François de. Voyage en Égypte et en Syrie, suivi de Considérations sur la guerre des Russes et des Turks. Tome II. Paris 1822, s. 365 a 369; GAULMIER, Jean. L'idéologue Volney. Beyrouth: Imprimerie catholique, 1951, s. 121, 310-311; LAS CASES, comte de. Le mémorial de Saint-Hélène. Tome I. Paris: Gallimard, 1956, s. 623. 
i spisovatelia. ${ }^{108}$ Memoáre ovplyvnili aj legendárne dielo Dobrodružstvá baróna Münchhausena od nemeckého básnika a prozaika Gottfrida Augusta Bürgera. ${ }^{109}$

Je potrebné pripomenút' aj zámorský ohlas Memoárov. Anglický preklad diela sa stal v roku 1789 najčastejšie vypožičanou knihou v New York Society Library! ${ }^{110}$

Životopisný prínos diela je mimoriadne skromný, chýbajú v ňom aj základné chronologické míl'niky. Autor o svojom súkromnom živote a rodine mlčí, robí len stručné odkazy na otcove diplomatické misie, ktoré významne ovplyvnili aj jeho životnú dráhu. Mladšieho brata, libertariánskeho dobrodruha Andrého de Totta, ${ }^{111} \mathrm{v}$ diele vôbec nespomína. Rovnako sa nič nedozvieme o jeho manželstve uzavretom v Konštantínopole či o rodinnom živote. Azda takýmto spôsobom chcel zabudnút' na svoje nevydarené manželstvo...

\section{Záver}

Po zosumarizovaní životnej dráhy Françoisa de Totta môžeme konštatovat', že sa v nej odrážajú významné zmeny francúzskej zahraničnej politiky v oblasti východnej Európy. Už v prípade jeho otca sme mohli vidiet', že pri výbere a výchove nádejných francúzskych diplomatov zohrali úlohu neskoré uhorské hnutia za nezávislost' a spoločné zahraničnopolitické záujmy Francúzska a Osmanskej ríše, ktoré smerovali k oslabeniu moci Habsburskej ríše. Takzvaná diplomatická revolúcia z roku 1756 zmenila od základov celoeurópsky systém aliancií a nové rakúsko-francúzske spojenectvo zásadne vylúčilo akúkolvvek podporu Uhorska v boji za nezávislost'. Knieža Choiseul sa pokúsil taktiež zabránit’ rastu vplyvu Ruska v Pol'sku, čomu mala poslúžit' d’alšia rusko-turecká vojna. Vyslanie baróna Totta na Krym sa uskutočnilo v rámci týchto predstáv. Misia bola úspešná, avšak účel jeho cesty bol odhalený a barón bol poverený d’alšími úlohami priamo v Konštantínopole. V konečnom dôsledku však misia nepriniesla požadované výsledky. Nezávislost' Pol'ska sa nedala obnovit', naopak, roku 1772 došlo k prvému deleniu a mier pri Küčük Kajnardži pre Osmanskú ríšu znamenal obrovské straty - obsadenie Krymu Ruskom. Tieto udalosti neodvratne odhalili zrýchlujúci pád tureckej moci, čo otvorilo cestu k „východnej otázke“, snahe

108 Profesor Meiners o diele píše takto: „Dies Werk ist vorzüglich desswegen wichtig, weil es die oft bezweyfelten Zeugnisse älterer Schriftsteller bestätigt. Ganz neue Data habe ich selten darinn gefunden. " Grundriss der Geschichte der Menschheit von C. Meiners ordentlichen Lehrer des Weltweisheit in Göttingen. Frankfurt; Leipzig 1786; strany diela nie sú očíslované.

109 BÜRGER; Gottfried August. Histoire et aventures du Baron de Münchhausen. Paris: Muquardt, 1840, s. 147.

110 HEROLD, Christopher. Bonaparte en Égypte. Paris: Plon, 1964, s. 15.

111 СТРОЕВ, Александр. „Те, кто поправляет фортуну” Авантюристь Просвещения. Moscou: Nouvelle Revue Littéraire, 1998, s. 339-340. ISBN 586793036. 
o rozdelenie Osmanskej ríše. V tomto smere podniklo kroky aj samotné Francúzsko. Zrodili sa plány na obsadenie Egypta, v čom zohrala významnú úlohu aj barónova cesta do Levanty.

Pri hodnotení života baróna de Totta si treba uvedomit', že jeho diplomatická aktivita obsiahla nanajvýš jedno desat'ročie $(1767$ - 1778), počas ktorého musel vykonávat' službu v často sa meniacich podmienkach. Bolo to síce obdobie zriedkavého mieru, avšak práve vtedy sa uskutočnila všeobecná reforma francúzskej armády, čo súviselo so stratami kolónií po sedemročnej vojne. Barón sa aktívne zúčastnil na týchto udalostiach, pričom jeho misie nemali len diplomatický, ale aj geostrategický, hospodárskopolitický či dokonca vedecký charakter. Nemožno zabudnút' aj na jeho literárnu činnost'. Ako sme videli, barón mal aj ambície spisovatel'a, ktoré vyvrcholili v napísaní Memoárov. Tie mu priniesli zaslúženú slávu nielen v Európe, ale aj v Amerike a isté zadost’učinenie za nie celkom úspešnú diplomatickú kariéru. V jeho diele sa odzrkadl'ujú idey osvietenstva a mnohí ho považujú za výnimočnú prácu z raného obdobia orientalistiky. ${ }^{112}$

Môžeme konštatovat', že barón de Tott bol typickým predstavitel'om versailleskej diplomacie, ktorých v časoch ancien régimu Francúzi zamestnali vo východnej Európe. Počas 17. a 18. storočia úlohou týchto všestranných agentov bolo spravidla len vyvolanie protihabsburských vojenských zásahov vo východoeurópskych štátoch bez toho, aby mali významný vplyv na politický vývoj. Výnimku tvorili len „samostatní“ agenti, dobrodruhovia, dezertéri alebo imigranti. Čiastočne aj ich aktivita podnietila rozvoj organizovaných francúzskych vojenských misií, prostredníctvom ktorých sa začali vojensko-technické a školské inštitucionálne a organizačné reformy vo východoeurópskych štátoch. ${ }^{113}$

* Príprava tejto štúdie bola zrealizovaná vd’aka pomoci Výskumnej skupiny rodových dejín Lendület Mad’arskej akadémie vied.

112 BERKES, Niyazi. The Development of Secularism in Turkey. London: Cambridge University Press, 1964, s. 68-69. ISBN 1850653496.

113 BODINIER, L. Gilbert. Les missions militaires françaises en Turquie au XVIIIe siècle. In Revue internationale d'histoire militaire, 1987, č. 68, s. 160-169. ISSN 0254-8186; HITZEL, Frédéric. Une voie de pénétration des idées révolutionnaires: les militaires français à Istanbul. In Varia Turcica, XIX, Mélanges offerts à Louis Bazin. L'Harmattan: Paris, 1992, s. 87-94. ISBN 2738416640; HITZEL, Frédéric. Un ingénieur français au service de la Sublime Porte: François Kauffer (1751?-1801). In Observatoire urbain d'Istanbul, Lettre d'information, 1994, č. 6, s. 17-24; TÓTH, Ferenc. Alliances de revers et modernisation militaire: le rôle des envoyés militaires français en Europe centrale et orientale, XVII $-\mathrm{XVIII}{ }^{\mathrm{e}}$ siècles. In SCHNAKENBOURG, Éric - DESSBERG Frédéric (eds.). La France face aux crises et aux conflits des périphéries européennes et atlantiques du XVIIe au XXe siècle. (Enquêtes et documents č. 39). Rennes: Presses Universitaires de Rennes, 2010, s. 143-153. EAN 9782753509948. 
FRANÇOIS DE TOTT (1733-1793)

DAS LEBEN UND DAS WERK EINES ERLEUCHTETEN DIPLOMATEN

\section{ZSOLT H O R B U L Á K - FERENC T Ó T H}

François de Tott gehört zu bemerkenswerten Persönlichkeiten des 18. Jahrhunderts. Sein Geburtsort ist Frankreich, wohin sein Vater, André Tott, nach dem Aufstand von Rákoczi auswanderte. Der letztere, geboren mit größter Wahrscheinlichkeit in Nitra, beteiligte sich an der Gründung der Husareneinheiten in Frankreich. Er diente in französischer Armee 35 Jahre lang und erreichte den Dienstgrad des Brigadiers. Er wurde ebenso mit diplomatischen Aufgaben beauftragt, die französische Regierung entsandte ihn ins Osmanische Reich. Sein Sohn François begann seine Karriere an der Seite des Vaters in einem Husarenregiment, doch sehr bald begab er sich auch auf die diplomatische Laufbahn. Er begleitete seinen Vater nach Konstantinopel, wo er acht Jahre verbrachte. Später wurde er auch mit selbständigen Aufgaben betraut, eine kurze Zeit war er in schweizerischem Neuchatel tätig, doch als Startpunkt seiner Karriere gilt seine Mission in Krim. Nach der Besetzung der Halbinsel ging er nach Konstantinopel, wo er zum Reformator der osmanischen Armee wurde. Er gründete ein Gusswerk für Kanonen, gründete eine moderne Artillerietruppe, baute Befestigungswerke in der Dardanellenenge sowie Pontonbrücke und führte die Einsatz von Bajonetten ein. Nach der Rückkehr nach Frankreich wurde François de Tott mit einer neuen Aufgabe beauftragt. Er wurde zum Verwalter der französischen Kolonien an der Mittelmeer-Ostküste ernannt und unternahm eine anderthalb Jahre lange Reise durch diese Region. Nach seiner Heimkehr wurde er zum Kommandanten der nordfranzösischen Festung Douai. Nach dem Ausbruch der Revolution verließ er Frankreich, um ins Land seiner Vorfahren, Österreich-Ungarn, zu kehren. Er ließ sich im kleinen Dorf Tatzmansdorf nieder, wo er kurz darauf verstarb. Er wurde publik dank seiner Memoiren Merkwürdigkeiten und Nachrichten von den Türken und Tataren, die bereits seinerzeit in mehrere Sprachen übersetzt wurden und sich bis heute der Gunst der Leser erfreuen.

Prof. Dr. Ferenc Tóth, DSc.

MTA BTK Történettudományi Intézet

1097 Budapest, Tóth Kálmán utca 4.

Budapest, 1453 Pf.: 33

Hungary

e-mail: toth.ferenc@btk.mta.hu

Ing. Mgr. Zsolt Horbulák, PhD.

Mierová 1

94301 Štúrovo

e-mail: horbulak@gmail.com 


\section{minulost' ako supermarket?}

spôsoby reprezentácie a aktualizácie dejín Slovenska

$$
\text { elena mannová }
$$

